\title{
ENSURING THE SUSTAINABILITY OF THE HUMAN RESOURCES MANAGEMENT SYSTEM OF MARITIME INDUSTRY ENTERPRISES
}

\author{
Alina Zaderei ${ }^{1}$ \\ ${ }^{1}$ National University «Odessa Maritime Academy», Odessa, Ukraine \\ e-mail: alyazaderey@gmail.com
}

Received: 01 July 2020; Accepted: 13 August 2020; Published: 01 September 2020

\begin{abstract}
The article examines the conditions for ensuring the sustainability of the human resources management system of maritime enterprises. The procedure of developing an international human resources management strategy is observed. It is proved that the transformation of the management system becomes a necessary condition for the productive competitive development of the enterprises of the maritime industry. It is established that the key factors of enterprise success is the strategy of international human resources management of maritime enterprises, which is a system of establishing time-bound possible directions of human resources development through the use of appropriate rules, means, analytical methods and management tools, which aim to reach the sustainability of human resources management system under the influence of environmental factors of the maritime industry. On the basis of the conducted research the formation of the strategy of management of the international human resources of the maritime enterprises, the model of maintenance of sustainability of the human resources management system, the system of methodological and economic and analytical support of strategic decisions are developed. The sequence of the stages of the strategic decisions formation dealing with sustainability of human resources management system of the maritime enterprises and the block complex of strategic decisions formations on steady functioning of the human resources management system of the sea transport enterprises are formed. Based on the review of the existing theory of expert research methods, we can say that it is necessary to develop that kind of a procedure of expert survey, which would fully meet the task of providing a strategic decision and would be convenient in practice and which will form the basis, information background for strategic decisions on the sustainability of the human resource management system.
\end{abstract}

Key words: human resources, maritime enterprises, management strategy, sustainability, economic and analytical support.

JEL classification: O15, J28, J24, Q56

How to Cite:

Zaderei, A. 2020. Ensuring the sustainability of the human resources management system of maritime industry enterprises. Access journal, ACCESS Press, 1(2): 146-156, https://doi.org/10.46656/access.2020.1.2(6)

\section{INTRODUCTION}

The analysis of factors that contribute the introduction of elements of international human resources management practices into the human resources management system, as well as factors that raise concerns about the need for such practices, gives the right to talk about opportunities and threats to the sustainability of the human resources management system. When formulating an appropriate human resources management strategy that would take into account the need to achieve an appropriate level of stability of the human resources management system, a difficulty is the lack of analytical procedures. The tooling and information support are meant. The particular emphasis should be placed on the lack of connection between the established level of system stability and the choice of the appropriate strategy, the lack of a mechanism for establishing 
the relationship between the factors of successful use of international human resources management and achieving the main goal of maritime enterprises which is the competitive development. Therefore, for the economic and analytical support development it is necessary to identify the problems and tasks of human resource management, the solution of which will create a basis for justifying the choice of the appropriate strategy that best meets the conditions prevailing in the maritime industry.

\section{Analysis of recent research and publications}

The studies of the implementation of approaches of the international human resources management in the practice of maritime enterprises management have begun to appear relatively recently: Armstrong (2006), Buzko (2009), Makarenko, Shaikhatdinov (2015), Fombrun, C.J., Tichy, N.M., \& Devanna, (1984), Oracle (2005), Petrova (2020), Schmerling, (2008).

The main emphases of the authors were on the context of application, namely, multinational corporations and large international companies. But the maritime industry is directly related to and close to international business. Therefore, the problems of international human resource management are of great interest and need research.

The purpose of the article is to study the conditions for ensuring the sustainability of the human resources management system of maritime enterprises.

\section{Results}

Modern operating conditions, a dynamic market environment have revealed an important component of the successful operation of human resources of maritime enterprises which is the level of adaptation to the environmental changes. Therefore, an important strategic issue is to establish the conditions for ensuring the sustainability of the human resources management system.

All this, as well as the principle of systematic management in the maritime sector provide an opportunity to develop a procedure for formulating a strategy for managing international resources in accordance with the action of various groups of environmental factors (Demyanchenko et al., 2017)

The strategy of international human resources management of maritime enterprises is a system of establishing time-bound possible directions of human resources development through the use of appropriate rules, means, analytical methods and management tools, which aim to achieve sustainability of human resources management under the influence of environmental factors maritime enterprises. The formed strategy should be characterized by complexity, have a hierarchical structure and determine different levels of strategic decisions. 


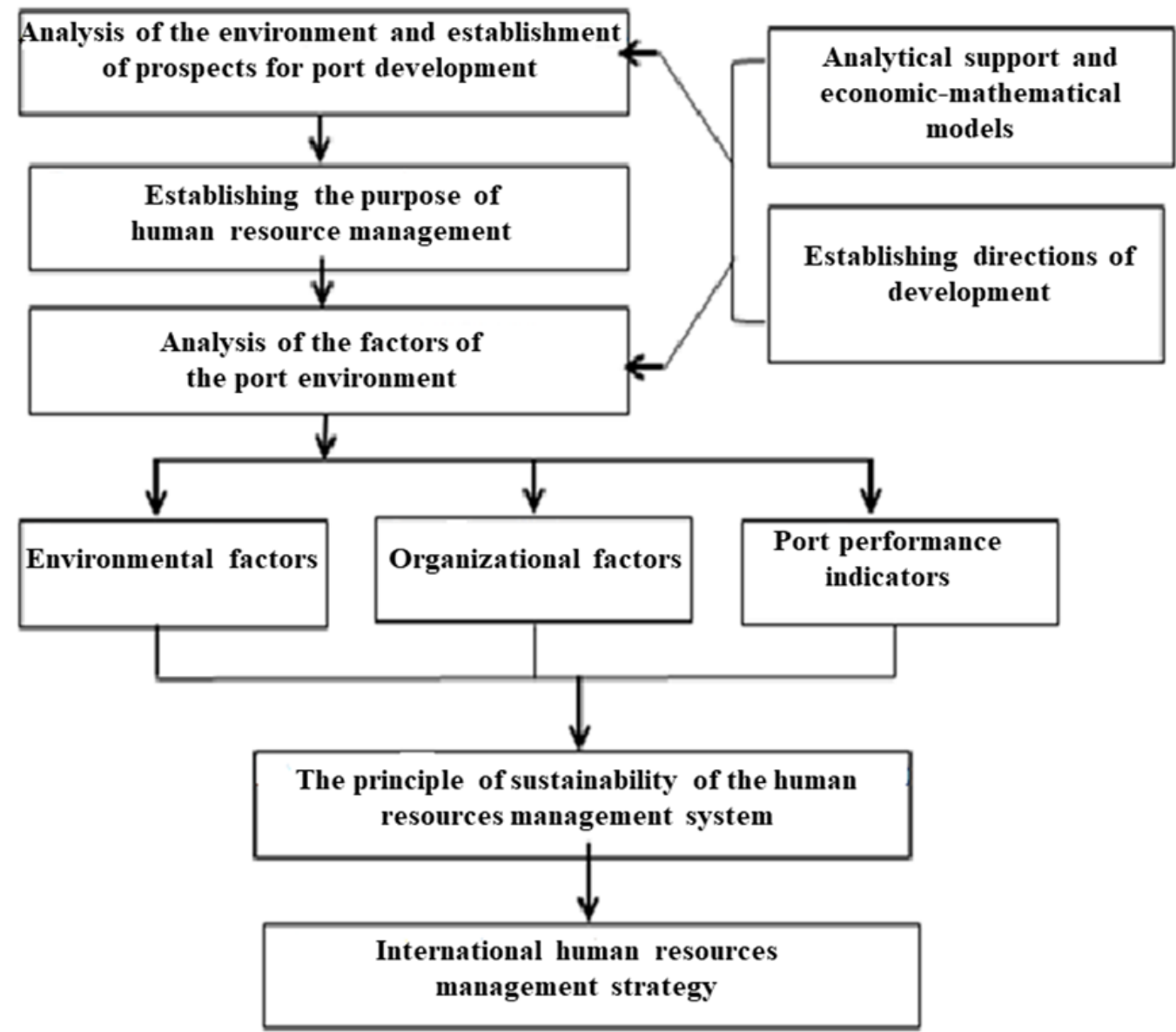

Fig.1. The procedure for forming the strategy of international human resources management of maritime enterprises Source: prepared by the author

Thus, it is necessary to implement the systematic approach to the development of the strategy of international human resources management of maritime enterprises, which will allow the most complete consideration of all the factors that directly affect the effectiveness of international human resources application. This will allow us to characterize all the existing interconnections in the human resources management system in the context of globalization and internationalization.

Therefore, the procedure of the international human resource management strategy development must be systemic. The scientific reasoning of management decisions on the use of international human resources on the basis of analytical processing of information is considered to be of the particular importance (Rachinskiy, 2012; Petrova et al., 2020)

The strategy is a systemic process, and therefore, the use of its main merit - consistency in combination with economic-mathematical models and analytical tools provides an opportunity to analyze the stability level of human resources management system taking into account all levels of hierarchical structure of the company and to set goals and objectives, to form possible directions of human resources development in the conditions of turbulent impact of environmental factors of the companies in the maritime industry. 
Studies of the factors that determine the sustainability level of the human resources management system, considering the proposed management principles, methods and tools, informational and analytical maintenance prove the need to develop fundamental strategic support for international human resources management that would fully meet the requirements of today's global market and its main development trends (Buzko, 2009; Buzko et al, 2016; Baklanova, Petrova, Koval, 2020; Sushchenko§Basyuk, 2019; Bacho et al, 2019; Mushkudiani et al, 2020).

The basis for ensuring the competitive development of maritime enterprises should be the stable human resource management system, which should function effectively and respond positively to the involvement of international human resources.

Thus, a necessary condition for the productive and competitive development of the companies in the maritime industry is the transformation of the human resources management system. Such a transformation involves adjusting to the level of high resilience and maximum use of the positive effects of environmental factors, such as environmental groups, organizational factors and productivity of maritime enterprises. Thus, let's present a model of competitive development of maritime enterprises based on the use of international human resources management system (fig. 2).

The developed model focuses on the sustainability of the human resources management system of maritime enterprises, focused on international human resources, preservation of their cultural values, traditions and creating appropriate conditions for their effective work in general, reducing conflicts, stressful situations, increasing productivity and efficiency of communication channels (Ustynov et al., 2019; Luchaninova et al., 2019).

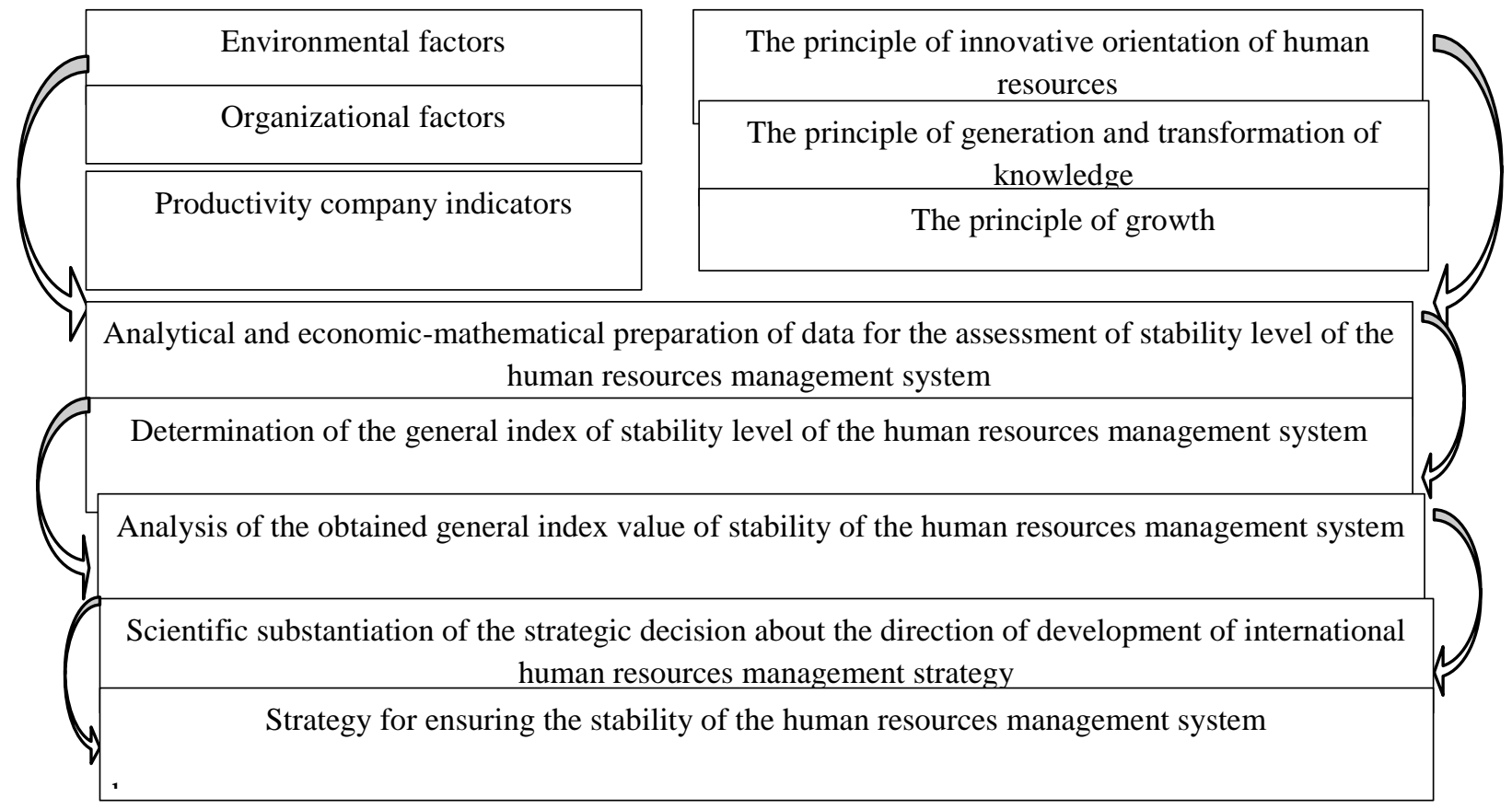

Fig. 2. Model of ensuring the sustainability of the human resources management system Source: prepared by the author 
As already mentioned, the consistency principle allows us to form a procedure for making strategic decisions (Rachinskiy, 2012).

Since appropriate tools are needed to make reasonable strategic decisions, such a system of methodological and economic-analytical strategic decisions support is shown on the fig.3. It includes two blocks: methodological support and economic-analytical support.

The system of methodological and economic-analytical support of strategic decisions is a grouped system of scientific approaches, models and methods that create the necessary support for the formation of the necessary complete research base.

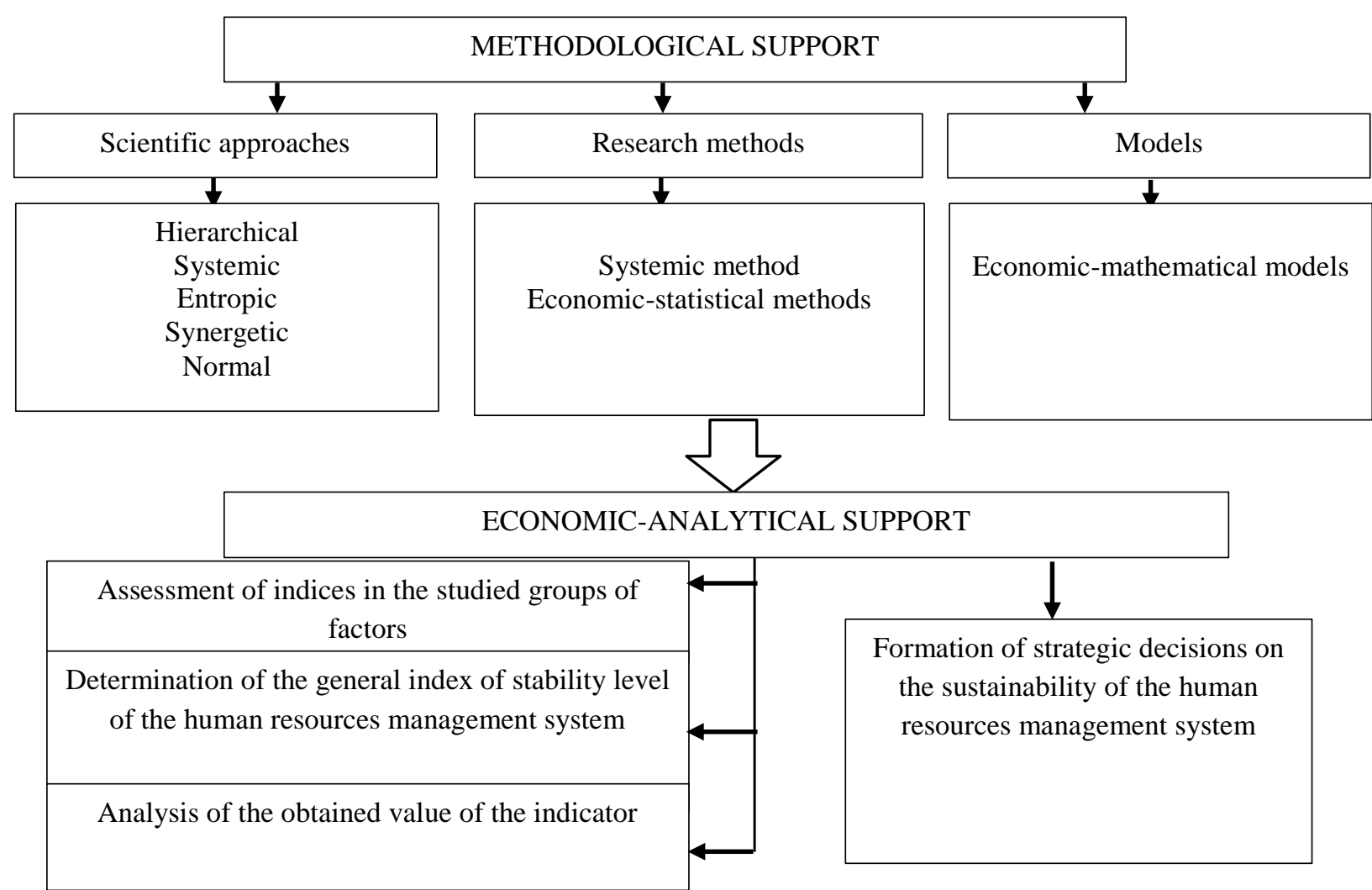

Fig.3. System of methodological and economic-analytical strategic decisions support Source: prepared by the author

The block of economic-analytical support includes a set of scientific-methodological approaches to determining the indices in each of the studied groups of factors, the level of stability of the human resources management system, analysis of obtained values and identifying the reasons that led to such results.

As for the practical implementation of providing strategic decisions on the sustainability of international human resources management system, it can be represented as a dialectical combination of elements of methodological and economic-analytical support system of strategic decisions (Nikolaieva et al., 2019).

It should be noted that the effect of priority factors for each of the studied groups is considered in terms of their positive impact on the use of international human resources. They are integrated to achieve the main goal 
of ensuring the sustainability of the human resources management system and the competitive development of the companies in the maritime industry.

To substantiate strategic decisions, appropriate methodological, informational, analytical support of the human resources management strategy has been formed (Oracle O, 2005; Mikhno, Koval, Kolesnikova, 2019).

The developed provisions for ensuring such decisions are based on the balancing principles of all the main elements, and consider the use of comprehensive analytical procedures, which mainly help to prepare a scientifically reasonable strategic decision. The factors that influence the implementation of international human resource management practices acquire the particular importance. The practical application of economic-analytical substantiation and support of strategic decisions on human resources management also requires the formation of a special procedure (fig. 4).

\begin{tabular}{|c|c|}
\hline $\begin{array}{l}\text { 1. Setting a goal, a set of tasks on strategic } \\
\text { human resource management }\end{array}$ & \multirow{2}{*}{$\begin{array}{l}\text { 2. Determining the factors and forming their groups that } \\
\text { determine the effectiveness of international human } \\
\text { resources, affect the value of the overall index of } \\
\text { sustainability of the human resources management } \\
\text { system }\end{array}$} \\
\hline \multirow{2}{*}{$\begin{array}{c}\text { 3. Establishing interconnections between } \\
\text { factors and the overall sustainability index } \\
\text { of the human resource management } \\
\text { system }\end{array}$} & \\
\hline & $\begin{array}{c}\text { 5. Optimization of general indicators of sustainability of } \\
\text { the human resources management system based on the } \\
\text { analysis of factors influencing international human } \\
\text { resources }\end{array}$ \\
\hline \multirow{2}{*}{$\begin{array}{l}\text { 4. Establishment of general indices and } \\
\text { indicators of sustainability of the human } \\
\text { resources management system }\end{array}$} & \\
\hline & $\begin{array}{c}\text { 6. Formation of strategic decisions to ensure the } \\
\text { sustainability of the human resources management } \\
\text { system }\end{array}$ \\
\hline
\end{tabular}

Fig. 4. The formation step sequence of strategic decisions to ensure the sustainability of the human resources (HR) management system

Source: prepared by the author

Such a procedure should have a logical sequence of appropriate steps in the development of strategic decisions in maritime HR management.

Thus, the established procedure of forming strategic decisions on maritime HR management has a clear logic that allows to achieve the most effective management decisions, using international human resources as well as the most productive usage of maritime enterprises in order to achieve goals and fulfill the tasks (Makarenko et al., 2015).

It should be noted that in the preparation process of decisions it can be influenced by lots of factors, it is advisable to use the examination methods (Ustinov, 2018). It is explained by the fact that in case of using incomparable factors of different groups of influence, it is a scientifically well-grounded examination that allows to collect and process the appropriate information as well as to obtain various information.

It is considered that, relying on the opinions of the experts, it is possible to get a real picture of a studied process, as the experts have a practical experience and theoretical knowledge in it. However, the usage of 
expert methods and the involvement of the experts themselves is in general a complicated task (Solokha et al., 2018).

Despite a rather wide and frequent usage of these methods, nowadays there are no generally accepted classifications and it is difficult to find all-round recommendations how to use them in a particular situation. This statement refers to all areas, such as an enterprise, industry or a country. So, it can be confirmed, that the expert methods continue to develop, as the modern tasks have a definite tendency to be complicated and take a great responsibility for the consequences of such decisions. Expert methods also significantly reduce the statistics of errors in decision-making by people responsible for it, as the involvement of specialists from different levels of management, as well as external representatives of other enterprises, allows a fairly professional approach how to come up with the problem.

Expert evaluation methods include the following important components:

- task analysis based on intuition and logic: the experts are expected to have sufficient experience, knowledge of the issue and are endowed with the appropriate intuition for the phenomenon under study, so the requirements are high for the expert who is under assignment;

-conducting direct qualitative or quantitative evaluation and analysis and forming a solution to the research problem and analysis of expected results;

- processing of all results of assignments on the researched problem for the formation of generalization of expert opinions.

Thus, based on the review of the definite theory of expert research methods, it can be claimed that each specific situation, problem requires the use of a set of characteristic methods and approaches. For example, there are sometimes significant inconveniences to expert surveys and complications associated with the conditions of such expert surveys (Sotnichenko et al., 2019).

It is necessary to develop such a procedure of expert survey, which would fully meet the task of providing a strategic decision and would be convenient in practical use. This procedure will form the basis, information base for strategic decisions on the sustainability of the HR management system.

It should be noted that the complexity of the HR management process is related to the human resources in particular, its specifics and general trends in the industry. For example, the processes of internationalization, globalization, which occur when international resources are connected to the management in various functional areas. Therefore, it is necessary to deal with people's reaction to various strategic decisions (Makarenko et al., 2015). In addition, the turbulence of events taking place in the world and in the industry creates uncertainty in the information space, the difficulty of obtaining information. Under such conditions, an appropriate methodological appliance for conducting an expert survey is required, which in such a situation will reduce the risks of uncertainty and making erroneous decisions.

Thus, as shown by the theoretical and practical experience of expert surveys and processing of their results in each case requires an individual approach to the problem, taking into account its specifics and require scientific justification of the subject. 
Providing strategic decisions with appropriate analytical procedures, the methods of expert assignments and technologies for processing the obtained results continue to become relevant, develop and improve. The set of elements that make up the procedure of forming strategic decisions for the sustainable operation of the HR management system of maritime transport enterprises is presented in Fig. 5.

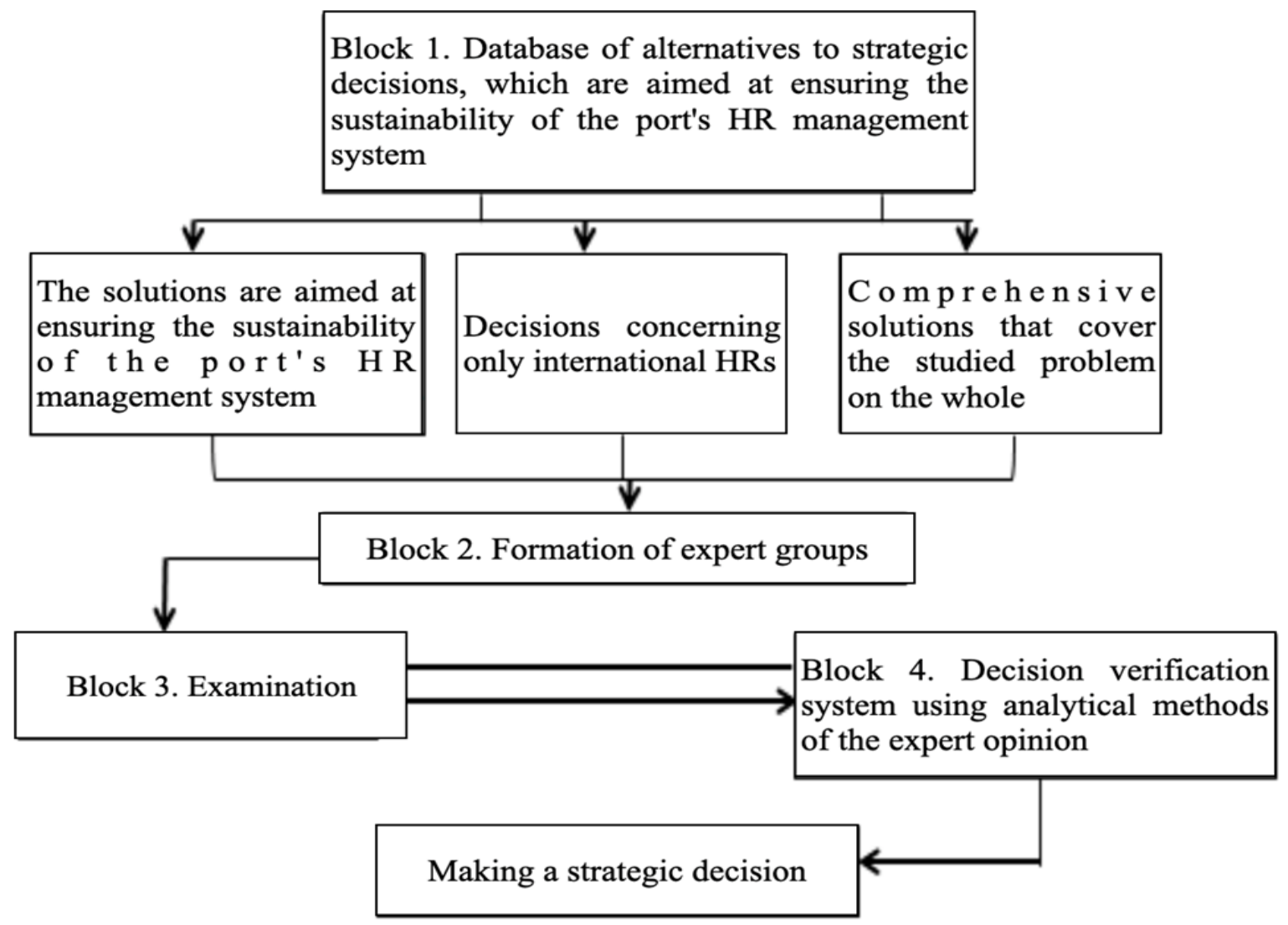

Fig.5. Block complex of strategic decisions formation on sustainable functioning of the HR management system of maritime transport enterprises

Source: prepared by the author

There are four blocks in the developed complex. From these blocks the procedure of development of the strategic decision is built based on several alternative variants.

It is necessary to emphasize certain features that are related to the process of alternatives formation of the strategic decisions. It is proposed to immediately divide them into such groups as those solutions aimed at ensuring the sustainability of the human resources management system of maritime transport enterprises and solutions that relate to purely international level and comprehensive ones that cover the problem as a whole (Ustinov, 2018; Koval, Kotlubay, Gorbachenko, 2018).

Based on a thorough analysis of the most widely used in practice expert methods, as well as taking into account the specifics of decision-making in the field of human resources management, method of expert evaluation was developed in accordance with the situation of maritime transport enterprises. The basis of such 
a symbiosis of expert assessments are some positive aspects of the Delphi method and the system of "assessment and study of events".

The procedure of such examination should take place in three stages.

The first and second stages focus on the opinions and experience of mainly practitioners, and the last one relies on the views and experience of senior management of maritime transport companies. The last one is the one who finally makes strategic decisions (Makarenko et al., 2019).

The third stage includes the examination procedure. Review of the assessments by experts should be noted as a circumstance. Each of them may not return to reviewing previously set points. However, in the event that an individual expert's grades fall out of the generally established intervals (such intervals will be obtained on the basis of all expert assessments), he must review his assessments to identify the reasons for the deviation.

Thus, each of the experts has the opportunity to adjust their assessments, based on the results of discussion of some issues with other experts and acquaintance with their point of view on the research question. In this way, the expert changes his mind and adjusts his assessments.

The senior management level of maritime transport enterprises should be able to scientifically substantiate and systematically approach decision-making to determine the strategic direction of work with human resources. This issue is particularly important for international human resources, as they have many specific factors that experts can assess and take into account in order to improve the efficiency of maritime transport enterprises (Onishchenko, 2018).

\section{CONCLUSIONS}

The system of interconnected methods, models, tools, information and analytical support allows to qualitatively form strategic decisions on human resources management, which are open for exchange of knowledge, experience, transformation of knowledge from the practices of foreign countries. Such a human resources management system will significantly increase the efficiency of all functional processes of maritime enterprises and make them competitive in the global market. In contrast to existing support systems, the current procedure focuses on a set of factors that determine the effectiveness of work with international human resources (external environment, organizational environment, productivity). The use of analytical mechanisms, models and methods allows to determine the quantitative relationships and between generalized indicators and factors.

It should be noted that in the preparation of decisions that take into account the influence of many factors, it is advisable to use methods of examination. Based on the review of the existing theory of expert research methods, it can be said that each specific situation and problem requires the use of a set of characteristic methods and approaches.

It is necessary to develop such a procedure of expert survey, which would fully meet the task of providing a strategic decision and would be convenient in practical use. An appropriate methodological apparatus for conducting an expert survey is needed, which in such a situation will reduce the risks of uncertainty and making 
wrong decisions. The use of expert assessments in the development of strategic decisions makes it possible to systematically approach the assessment, to take into account the action of each individual environmental factor with the definition of possible directions for the maritime enterprises' events development. Therefore, in general, conditions must be created to ensure the sustainability of the human resources management system of maritime enterprises.

\section{Conflict of interests}

The authors declare no conflict of interest.

\section{References}

Armstrong, M. (2006). A Handbook of Human Resource Management Practice. London: Kogan Page.

Bacho, R., Pukala, R., Hlibko, S., Vnukova, N., Pola, P. (2019). Information Management: the Key Driver of the Economic System's Development. Marketing and Management of Innovations, 3, $297-307$. http://doi.org/10.21272/mmi.2019.3-23

Baklanova, O., Petrova, M., Koval, V. (2020). Institutional Transmission in Economic Development. Ikonomicheski Izsledvania, 29(1), 68-91.

Buzko, I.R. (2009). Strategic management of the personnel of the enterprise in the minds of the current development of the market. Lugansk: View of SNU im. V. Dahl.

Buzko, I., Dyachenko, Y., M Petrova, N Nenkov, D Tuleninova, K Koeva. (2016). Artificial Intelligence Technologies in Human Resource Development. Computer Modelling and New Technologies, Riga, Latvia, 20(2) 26-29.

Demyanchenko A.G., Makarenko M.V., Sotnychenko L.L. (2017). In addition to the organizational and economic mechanism of management of the development of enterprises in the sea field. Odessa: NU "OMA".

Derikhovskaya V.I. (2013). Personnel management strategy: its types and features. Scientific Bulletin, 10(189), 37-50.

Fombrun, C.J., Tichy, N.M., \& Devanna, M.A. (1984). Strategic Human Resource Management. New York: Wiley \& Sons Ltd.

Koval, V., Kotlubay, V., Gorbachenko, S. (2018). State and features of improvement of mechanisms regulation of port industry of Ukraine. Economy and Society, 16, 144-149

Luchaninova, O., Koval, V., Deforzh, H., Nakonechna, L. \& Golovnia, O. (2019). Formation of communicative competence of future specialists by means of group work. Espacios, 40 (41), 11.

Makarenko, M.V., Shaikhatdinov, A.Z. (2015). Analysis of knowledge management practices in the world's leading ports. Bulletin of Priazovsky State Technical University, 30, 349-357.

Makarenko, M.V., Zaderei, A.E. (2019). Research of conditions of introduction of practice of the international management of human resources in ports. Bulletin of Priazovsky State Technical University, 37(5), 72-78.

Mikhno, I., Koval, V., Kolesnikova, K. (2019). State regulation of social capital in the context of social security. Derzhavne upravlinnya: udoskonalennya ta rozvytok, 11. DOI: 10.32702/2307-2156-2019.11.38

Mushkudiani, Z., Gechbaia, B., Gigauri, I., Gulua, E. (2020). Global, economic and technological trends in human resource management development. Access journal, ACCESS Press, 1(1): 53-60. DOI: https://doi.org/10.46656/access.2020.1.1(4)

Nikolaieva L., Haichenia O., Omelchenko T., Kozlova V. (2019). Tools for Rating Evaluation of Human Resources as the Main Factor for Providing the Innovation Development of the Sea Ports. Advances in Economics, Business and Management Research, Published by Atlantis Press, 99, 266- 271.

Onishchenko, V.V. (2018). Assessment of the state of management of innovative activity of human resources of sea trade ports. Scientific Journal Manager, 2(79), 136-141.

Oracle O. (2005). Human Capital Management, People Management. London.

Petrova, M., Koval, V., Tepavicharova, M., Zerkal, A., Radchenko, A., \& Bondarchuk, N. (2020). The interaction between the human resources motivation and the commitment to the organization. Journal of Security \& Sustainability Issues, 9(3): 897-907. https://doi.org/10.9770/jssi.2020.9.3(15) 
Petrova, M., Davidavicius, S., Borysova, L. (2019). International human resources experience in hotel industry. Proceedings of the 1 st International Symposium on Intellectual Economics, Management and Education, September 20, 2019. Vilnius Gediminas Technical University. Vilnius: Vilnius Gediminas Technical University, 2019. 396 p., ISBN 978-619-00-1036-4, Publisher: FABER Ltd, 87-89

Rachinskiy A.P. (2012). Strategic personnel management: theoretical and methodological analysis. State management: more sophisticated and development, 3.

Sardak, O.V. (2014). Research of conceptual approaches in the field of strategic personnel management. Economic strategy and prospects for the development of trade and services, 1(19), 226-235.

Schmerling, D.S. (2008). Application of expert assessments for strategic planning tasks. M.: MShE MSU TsSP, 36.

Solokha, D., Sotnichenko, L., Bessonova, S., Kravchenko, A. (2018) Justification of business entities development based on innovative principles. Academy of Strategic Management Journal, 17(5), 1-8.

Sotnichenko, L.L., Zaderei, A.E. (2019). Officials of the efficiency of international management of human resources in seaports. Bulletin of Donetsk State University of Management, 4(85), 85-94.

Sushchenko, O., Basyuk, D. (2019). Organization of Personnel Training in the HR-Management System at MachineBuilding Enterprises. X International Scientific and Practical Conference "Innovations in Mechanical Engineering" (ISPCIME-2019). MATEC Web of Conferences, EDP Sciences, vol.297 (07006), 2019, DOI: https://doi.org/10.1051/matecconf/201929707006

Ustinov R.G. (2018). Organizational culture at the enterprises of the maritime industry. Scientific Journal Manager. Bulletin of Donetsk State University of Management, 2(79), 142-147.

Ustynov R., Babachenko M., Sienko O. (2019). Creating the Approach for the Evaluation Level of the Efficiency of the Organizational Culture of the Sea Port. Advances in Economics, Business and Management Research, Published by Atlantis Press, 99, 249- 254.

\section{About the author:}

Alina ZADEREI, Senior Lecturer, National University «Odessa Maritime Academy», Odessa, Ukraine. Research interests: human resources management, maritime enterprises, business administration, economic and analytical support, sustainable development.

ORCID ID: https://orcid.org/0000-0002-9660-986X

\section{Copyright (C) 2020 by author(s) and ACCESS Publishing Press This work is licensed under the Creative Commons Attribution International License (CC BY)}

